\title{
Validated TLC-densitometry method for determination of cetirizine dihydrochloride in tablet dosage form
}

\author{
*Nia Kristiningrum, Ellsy Novita Martyanti \\ Research and Development centre in Laboratory of Chemical Pharmacy, Jember University, East java, Indonesia
}

\begin{abstract}
A rapid, reproducible and accurate TLC method was developed for the determination of Cetirizine Dihydrochloride in tablet. The analytes were dissolved with ethanol 70\% and chromatographed on silica Gel GF 254 TLC plate using chloroform : methanol : ethyl acetate in the ratio of $2: 7: 3(\mathrm{v} / \mathrm{v})$ as mobile phase. Quantitative analysis was done through densitometric measurement at wavelength $234 \mathrm{~nm}$. Method was found linear over the concentration range of $400-1600 \mathrm{ng} / \mathrm{spot}$ with the correlation coefficient of 0.996. Specificity showed calculation of purity and identity more than 0.99 . The limit of detection (LOD) and the limit of quantification (LOQ) of the method were 75.54 and $226.64 \mathrm{ng} / \mathrm{spot}$. The relative standard deviation of this method was $0.86 \%$ whereas the means of the recovery data was $100.54 \pm 0.11 \%$. The proposed method has been applied to the determination of Cetirizine Dihydrochloride in commercial tablet formulations and the result were $96.97 \pm 0.86 \%$ for brand $\mathrm{A}$ and $100.57 \pm 1.17 \%$ for brand $\mathrm{B}$. The developed method was successfully used for the assay of Cetirizine Dihydrochloride. This method is simple, sensitive and precise; it can be used for the routine quality control testing of marketed formulations.
\end{abstract}

Key Words: Cetirizine Dihydrochloride, validation, TLC densitometry, tablet, chromatography method.

\section{INTRODUCTION}

Cetirizine Dihydrochloride (CTZ) (Figure 1) is the dihydrochloride of 2-(4-(4-chlorobenzhydryl)piperazin-1yl) ethoxyacetic acid, a non-sedating type histamine H1receptor antagonist is used, mainly, in symptomatic treatment of seasonal rhinitis and conjunctivitis, perennial allergic rhinitis as well as pruritus and urticaria of allergic origin (Reynolds, 1996). It is used to treat several allergy symptoms, including runny nose, sneezing, Itchy or watery eyes and Itchy nose or throat. Analytical method including spectrophotometric (Walily et al., 1998) and HPLC (Arayne et al., 2008) have been reported for the determination of Cetirizine Dihydrochloride. The disadvantages of those methods are disability to analyze several samples simultaneously in parallel and need much solvents as mobile phase. In this presentation, we report a simple and rapid assay with sufficient sensitivity for the quantitation of CTZ using TLC densitometry method. The objective of this study was to develop, optimize and validate a simple and rapid TLC densitometry method for determination of CTZ in tablets.

\section{EXPERIMENTAL}

\section{Material and reagents}

Cetirizine Dihydrochloride working standard (Glochem Industries Limited, India), ethanol, methanol, chloroform and ethyl acetate (Merck, Germany). Commercial tablets contain Cetirizine Dihydrochloride were procured from local chemist shop.

Preparation of standard solution \& pharmaceutical samples Standard solution was always freshly prepared by dissolving $50 \mathrm{mg}$ of CTZ in ethanol $70 \%$ ad $25 \mathrm{ml}$. The standard solution of CTZ (2000 ppm) was diluted to get

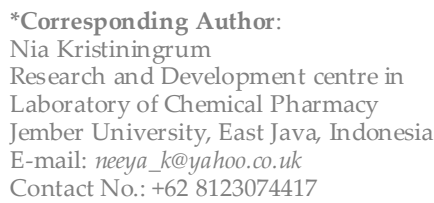

solutions in concentration range of 200-800 ppm. For sample preparation, a total of 20 tablets containing CTZ as the active ingredient were weighed and finely powdered. A portion of the powder equivalent to $5 \mathrm{mg}$ CTZ was weighed accurately, transferred to a $10 \mathrm{ml}$ volumetric flask and suspended in $5 \mathrm{ml}$ ethanol $70 \%$. The flask was placed in ultrasonic bath before completion to volume with the same solvent.

\section{Chromatographic condition}

Planar chromatography was performed by spotting the sampel on precoated TLC silica gel GF $254(20 \times 10 \mathrm{~cm})$ using $2.0 \mu \mathrm{l}$ glass capillaries. A Camag Twin Through Chamber containing a mixture of chloroform : methanol : ethyl acetate $(2: 7: 3)(\mathrm{v} / \mathrm{v})$ was saturated. The spots move to a distance of $9 \mathrm{~cm}$. Densitometric scanning was performed on Camag TLC Scanner 3 in the absorbance mode at $234 \mathrm{~nm}$ for all measurements. The slit dimension was kept at $6.00 \mathrm{~mm} \times 0.30 \mathrm{~mm}$ and a scanning speed of $20 \mathrm{~mm} / \mathrm{s}$ was employed. Cetirizine Dihydrochloride was detected at $\mathrm{Rf}$ 0.49. Quantitative evaluation was performed via peak areas by WinCats software (version 1.4.1.8154).

\section{Method validation}

The developed method was validated in accordance with the procedures described by Kristiningrum et.al. (2012).

\section{Specificity}

The Specificity of this method was determined by analyzing standard and sample. Specificity was showed by purity and identity test that determined by scanning at $200 \mathrm{~nm}-400 \mathrm{~nm}$. Calculations for identity checks ( $r S . S$ and $r S, A$ where $\mathrm{S}$ is spectrum standard and $\mathrm{A}$ is spectrum sample and purity checks ( $r S, \mathrm{M}$ and $r \mathrm{M}$, E where $\mathrm{S}=$ start, $\mathrm{M}=$ center; and $\mathrm{E}=$ end of spectrum).

\section{Linearity}

The evaluation of the calibration curve's linearity was done based on spots of the standard solutions prepared in 


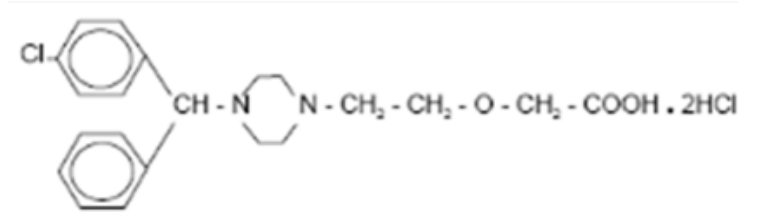

Figure 1. Structure of Cetirizine dihydrochloride.

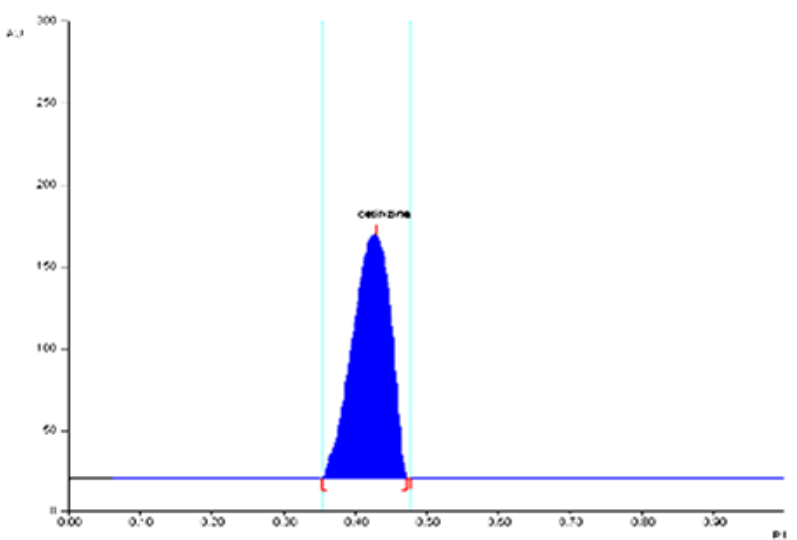

Figure 2: Densitogram of standard Cetirizine Dihydrochloride (Rf: 0.43), mobile phase chloroform : methanol : ethyl acetate $(2: 7: 3 \mathrm{v} / \mathrm{v})$.

ethanol $70 \%$ at the concentrations $200,400,450,300,533$, 600,700 , and $800 \mathrm{ppm}$. The $2 \mu \mathrm{l}$ of each of these solutions was spotted on the TLC plate Peak area was record for each concentration and a calibration curve was obtained by plotting peak area vs concentration.

Limit of detection and quantification

Standard solution were prepared at the concentration 80 , 120, 160, 280, 320, 360 and $400 \mathrm{ppm}$. The $2 \mu \mathrm{l}$ of each of these solutions was spotted on the TLC plate. Peak area was recorded for each concentration. Limit of detection (LOD) and Limit of Quantification (LOQ) were determined using software validation method version 1.13 .

\section{Precision}

The precision of this method was performed by repeatability and intermediate precision studies. Repeatability studies was performed by analyzing one concentration of the drug for six times on the same day. The intermediate precision was checked by repeating studies on three different days.

\section{Accuracy}

The accuracy of this method was evaluated through recovery experiments by adding three different amounts of Cetirizine Dihydrochloride standards i.e. 30, 45 and $60 \%$ of the concentration samples. Each concentration were replicated $(n=3)$.

\section{Analysis of marketed formulations}

The Samples that is contain of Cetirizine Dihydrochloride (brand A and brand B) were prepared as sample preparation method. Each of samples were replicated $(n=3)$ and spotted on plates. The analysis was done in the same way as described earlier.
Table 1: Optimum condition for analysis of Cetirizine dihydrochloride.

\begin{tabular}{ll}
\hline Parameters & Data \\
\hline Solute & Ethanol 70\% \\
Eluent & Chloroform : methanol : ethyl \\
& acetate $=2: 7: 3(\mathrm{v} / \mathrm{v})$ \\
Stationary phase & Silica gel GF 254 \\
Wavelength & $234 \mathrm{~nm}$ \\
Concentration optimum & $500 \mathrm{ppm}$ \\
\hline
\end{tabular}

Table 2: Result of precision evaluation of Cetirizine dihydrochloride.

\begin{tabular}{cc}
\hline Measurement $^{\text {a }}$ & RSD value (\%) (n=6) $\mathbf{~}^{\mathbf{b}}$ \\
\hline 1 & $0.76 \%$ \\
2 & $0.98 \%$ \\
3 & $0.85 \%$ \\
Average RSD & $0.86 \%$ \\
\hline aEach measurement was perfomed by the same analyst and on a different
\end{tabular}

aEach measurement was perfomed by the same analyst and on a different plate and different days

bEvaluted by one analyst on one plate (repeatability)

Table 3: Accuracy result of Cetirizine dihydrochloride commercial tablets.

\begin{tabular}{lllc}
\hline Analyte & $\begin{array}{l}\text { Label claim [\%] } \\
\text { (mean } \pm \text { SD) }\end{array}$ & $\begin{array}{l}\text { Added } \\
{[\%]}\end{array}$ & Recovery \\
\hline Cetirizine & $100.65 \pm 1.164 \%$ & $30 \%$ & $100.66 \pm 0.10 \%$ \\
dihydrochloride & & $45 \%$ & $100.51 \pm 0.11 \%$ \\
& & $60 \%$ & $100.44 \pm 0.12 \%$ \\
& Avg. recovery \pm SD & & $100.54 \pm 0.11 \%$ \\
\hline
\end{tabular}

Table 4: Validation parameters for standard Cetirizine dihydrochloride.

\begin{tabular}{ll}
\hline Parameter & Cetirizine dihydrochloride \\
\hline Specificity & Purity test $\geq 0.99$ Identity test $\geq 0.99$ \\
Linierity & $\mathrm{r}=0.996 \mathrm{Vxo}=3.451 \%$ \\
Sensitivity & LOD $=75.54 \mathrm{ng} / \mathrm{spot}$ \\
& $\mathrm{LOQ}=226.64 \mathrm{ng} / \mathrm{spot}$ \\
Precision & Average $\mathrm{RSD}=0.86 \%$ \\
Accuracy & Average recovery $\pm \mathrm{SD}=100.54 \pm 0.11 \%$ \\
\hline
\end{tabular}

Table 5: Results of analysis of Cetirizine dihydrochloride in pharmaceutical formulation.

\begin{tabular}{ccc}
\hline No. & Formulation & $\begin{array}{c}\text { \%Recovery } \pm \text { SD of } \\
\text { Cetirizine dihydrochloride }\end{array}$ \\
\hline 1. & Brand A & $96.97 \pm 0.86 \%$ \\
2. & Brand B & $100.57 \pm 1.17 \%$ \\
\hline
\end{tabular}

\section{RESULTS AND DISCUSSION}

\section{Optimum Condition}

Table 1 showed the optimum conditions for analysis of Cetirizine Dihydrochloride using TLC densitometry. The mobile phase of chloroform : methanol : ethyl acetate $(2: 7$ : 3) $(\mathrm{v} / \mathrm{v})$ give the efisien chromatogram. Efficiency of chromatogram was evaluated by the value of Number of Theoritical Plate $(\mathrm{N})$, Height Equivalent to a Theoritical Plate $(\mathrm{H})$ and resolution (Rs). The Rf of analytes are 0.43 (figure 2). Concentration optimum for Cetirizine Dihydrochloride was $500 \mathrm{ppm}$.

\section{Method validation}

From the TLC densitometry, showed that analyte spots in samples were identical with standards. Purity check of the 
analyte spots using winCATS software also showed that analyte spots were pure. The values of $\mathrm{rS}, \mathrm{M}$ and $\mathrm{rM}, \mathrm{E}$ were $>0.999$, demonstrating that proposed TLC method is highly specific. Linierity of Cetirizine Dihydrochloride give the equation $\mathrm{Y}=300.403+2.784 \mathrm{X}$ with correlation coefficient (r) 0.996. The LOD and LOQ (Limit Detection and Quantitation) were found to be 75.54 and 226.64 ng/spot. All the values of the repeatability and intermediate precision evaluation were less than $2 \%$ (table 2 ). The three measurement were perfomed within one laboratory by same analyst on different plates and different days. The accuracy of the proposed method were $100.54 \pm 0.11 \%$ (table 3 ). The summary of data validation parameters as listed in table 4.

\section{Analysis of Marketed formulations}

The result of the analysis of marketed formulations brand $\mathrm{A}$ and brand $\mathrm{B}$ showed that there was no interference from the excipients. The result given in table 5 .

\section{CONCLUSION}

A new TLC method has been developed for the identification and quantification of Cetirizine Dihydrochloride. The method was found to be simple, rapid, specific, sensitive, precise and accurate for estimation and can be conveniently employed for the routine quality control analysis of Cetirizine Dihydrochloride in tablet.

\section{REFERENCES}

Arayne, M. S., Sultana, N., \& Nawaz M. (2008) Simultaneous Quantification of Cefpirome and Cetirizine or Levocetirizine in Pharmaceutical Formulations and Human Plasma by RP-HPLC. Journal of Analytical Chemistry; Vol. 63(9):881-887 [DOI]

Indrayanto, A., Gunawan I., \& Muhammad, M. (2003) Validation Method of Analysis v1.03. Software from General Public Licence. Faculty of Pharmacy, Surabaya, Airlangga University.

Kristiningrum, N. And Rakhmawati, M. (2012) Simultaneous Determination of Chloramphenicol and Hydrocortisone Acetate in Cream Using TLC Densitometry Method. International Current Pharmaceutical Journal; 2(1):7-10 [DOI]

Reynolds J.E.F. (Ed.), (1996) Martindale-The Extra Pharmacopoeia, 31st ed. Pharmaceutical Press, London, p. 436.

Walily, AF., Korany, MA., Gindy, A. and Bedair, MF. (1998) Spectrophotometric and High Performance Liquid Chromatographic Determination of Cetirizine Dihydrodhloride in Pharmaceutical Tablets. J. Pharm Biomed Anal, 17(3):435-442 [DOI] 